\title{
New lakes in deglaciating high-mountain regions - opportunities and risks
}

\author{
Wilfried Haeberli ${ }^{1}$ • Michael Buetler ${ }^{2}$ • \\ Christian Huggel ${ }^{1}$ - Therese Lehmann Friedli $^{3}$. \\ Yvonne Schaub $^{1}$ • Anton J. Schleiss ${ }^{4}$
}

Received: 8 February 2016/Accepted: 9 August 2016/Published online: 31 August 2016

(C) Springer Science+Business Media Dordrecht 2016

\begin{abstract}
In connection with the ongoing disappearance of glaciers in cold mountains, a great number of new lakes come into existence. The sites and approximate formation time of such potential new lakes can be realistically modelled. This provides an important knowledge base for planning the management of at least the larger ones among such lakes. New water bodies can markedly increase the hazard and risk potential for down-valley areas in the long term, especially in relation to impact/flood waves triggered by rock/ice avalanches from the steep icy peaks surrounding them. However, they also offer opportunities for use in connection with tourism, water supply and hydropower production. Legal regulations and aspects of landscape protection and nature conservation have to be thereby carefully considered. Possible synergies and conflicts exist; they can be anticipated at an early stage by a matrix-type analysis of interrelations between the different perspectives involved. A corresponding inter- and transdisciplinary study was performed for the currently glacierized areas of the Swiss Alps. The results of this study may serve as an example for dealing with the consequences of rapid climate-induced changes in other populated regions with rugged icy mountains, such as the Peruvian Cordilleras or the Himalaya-Karakoram region.
\end{abstract}

Electronic supplementary material The online version of this article (doi:10.1007/s10584-016-1771-5) contains supplementary material, which is available to authorized users.

Wilfried Haeberli

wilfried.haeberli@geo.uzh.ch

Geography Department, University of Zurich, 8057 Zurich, Switzerland

2 Gloriastrasse 66, 8044 Zurich, Switzerland

3 Center for Regional Economic Development (CRED), University of Bern, 3001 Bern, Switzerland

4 Laboratory of Hydraulic Constructions (LCH), Ecole polytechnique fédérale de Lausanne (EPFL), 1015 Lausanne, Switzerland 


\section{Introduction}

As a consequence of continuing atmospheric temperature rise, glacier and permafrost landscapes in cold mountain ranges undergo drastic changes. Such changes have the potential to affect large surrounding regions (cf. supplementary material S1). Glaciers in most icy mountain ranges are shrinking rapidly and may even largely disappear within the coming decades (Zemp et al. 2006; 2015; cf. supplementary material S2). Numerous small and large new lakes form where topographic depressions (glacier-bed overdeepenings) become exposed as glaciers are vanishing (Figure 1). These lakes are - albeit less than the original glaciers - attractive landscape elements and interesting for hydropower production and freshwater supply. However, they can also pose the inherent danger of generating lake outburst floods. When assessing the risks related to the latter the decreasing stability of slopes on nearby icy peaks affected by glacier de-buttressing and permafrost degradation also needs to be addressed (Haeberli et al. 2016).

Adaptation strategies to such developments should aim at assessing/reducing risks related to the new conditions and try to make the best use of possible new options. This requires holistic approaches to be applied for anticipating changes in complex/highly interconnected natural systems. In addition, trends and options of human action/expansion and of saving economic costs need to be addressed if risks can be managed or even reduced (Faulkner 2001; McEvoy et al. 2008; Ritchie 2008).

Simulating future landscapes and related processes in still glacier-covered and permafrostaffected regions is an emerging research field providing a knowledge base and planning tool

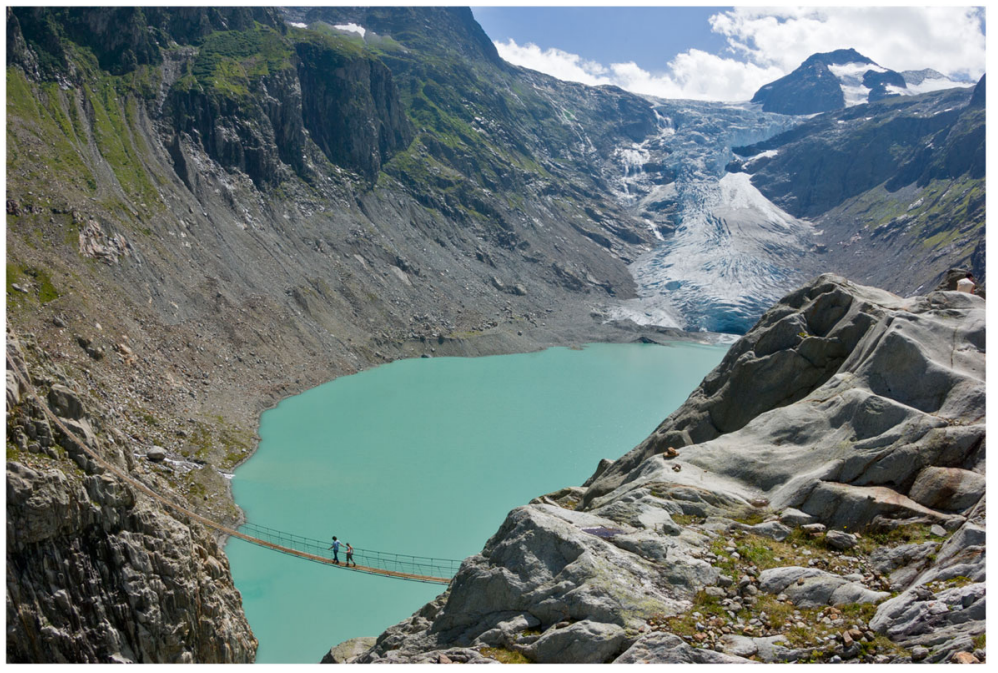

Fig. 1 A new lake formed since the turn of the century at the retreating Trift glacier (Swiss Alps; cf. Figure 2). A hanging bridge has been installed across a deep gorge at the lower lake end to enable access to a mountain hut of the Swiss Alpine Club on the orographic right valley side (left side in the image). The hut could be reached by crossing the glacier surface before lake formation. This hanging bridge and the new lake have become a remarkable tourist attraction. An early warning system has been installed to protect tourists and people in the valley against possible impact/flood waves triggered by ice or rock avalanches into the lake. Plans exist for creating a lake reservoir for hydropower production (and flood protection?) with a dam; this reservoir would ultimately reach a level higher than the that of the bridge (cf. Figure 3). Photograph J. Alean 2007 
for multiple users (Figure 2; cf. supplementary material S3). Such a product of science can show options for future action (Huggel et al. 2015). However, the goals of any envisaged developments - for instance spatial planning, landscape protection or water supply - must be harmonized among relevant stakeholders. Moreover, ways of transforming the results into the real world have to be found, such as the funding of infrastructure. Various possible synergies exist but potential legal and/or political conflicts may also arise, and time for finding sustainable solutions can be limited.
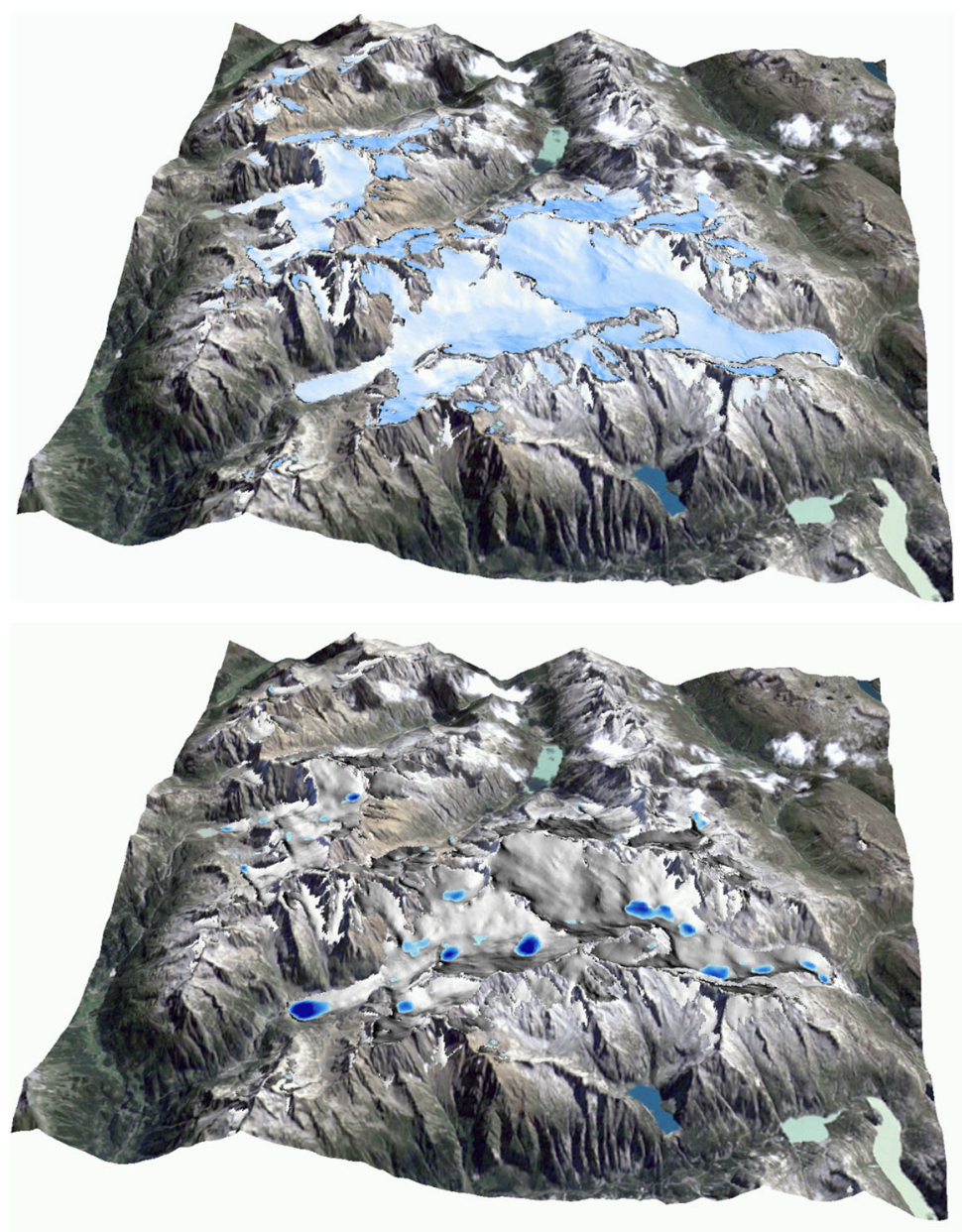

Fig. 2 Simulation of bed overdeepenings as sites of potential future lake formation at the glaciers Trift (left) and Rhone (right) in the Swiss Alps, with (top) and without (bottom) glacier cover. Computing was performed with the GlabTop model (Linsbauer et al. 2012) and digital terrain information from the 1970s, i.e. well before the formation of the new lakes at the lower margins of Trift glacier (left; cf. Figure 1) and Rhone glacier (right; cf. supplementary material S3). A system of lakes is likely to form and must be considered in connection with plans for hydropower production, flood protection, touristic development or landscape protection. The existing hydropower lake reservoirs Grimsel (large) and Räterichsboden (smaller) of the Kraftwerke Oberhasli are visible in the lower right corner. The hydropower lake reservoir of Göscheneralp can be seen in the upper-central part. Simulation and graph A. Linsbauer, University of Zurich 
A comprehensive inter- and transdisciplinary study on opportunities and risks related to new lakes forming in de-glaciating areas was carried out in the Swiss Alps (NELAK 2013). The corresponding experience and knowledge base is summarized in this paper. This may help with comparable studies in other populated high-mountain regions of the world. First steps in this direction have been undertaken in the meantime. An inventory of possible future lakes has been prepared for the Peruvian Cordilleras (Colonia et al. 2015), and thousands of sites with glacier-bed overdeepenings and potential future lake formation have been spatially simulated for the entire Himalaya-Karakoram region with a glacier surface area of over $40,000 \mathrm{~km}^{2}$ (Linsbauer et al. 2016). Current and future risks from glacial lake outburst floods have been assessed in an integrative and anticipatory approach for the Himachal Pradesh, India (Allen et al. 2016). Such efforts must be understood as initial steps of a continual reflection process that requires going beyond individual scientific disciplines.

\section{Possible uses and hazards related to new lakes}

The new lakes are primarily interesting with a view to questions of water supply, hydropower production, touristic development, hazard prevention and landscape protection/nature conservation.

\subsection{Water supply}

The massive shrinking of short- and long-term snow and ice reserves in cold mountains causes a strong change in the seasonality of melt water runoff and water supply to lower valleys and surrounding lowlands (Seibert et al. 2014). Serious water shortages for settlements and agriculture can result in regions with pronounced warm/dry seasons, especially in combination with socio-economic stresses (Drenkhan et al. 2015; French et al. 2015). The new lakes could therefore partially replace the vanishing melt water supply in critical situations. The available water volume in naturally formed depressions, however, is strongly limited. In the Swiss Alps, for instance, the total water volume of the anticipated future lakes is some $3 \%$ of the presently existing glacier volume (Linsbauer et al. 2012), and roughly corresponds to that of one average annual precipitation sum over the still glacier-covered surface. At best, small percentages of the lake volume can be used for freshwater supply, but even this limited use would require major infrastructure (tunnels, dams) and corresponding investment. Therefore, realistic options exist for a few cases only, especially where large lake volumes could be enhanced by dam construction (cf. Farinotti et al. 2016). Moreover, new lakes - whether natural or artificial must be carefully examined with respect to (1) the resulting change in the hazard/risk situation, (2) the regulations concerning protected areas and/or (3) the water management in relation to hydropower schemes. Much more promising perspectives relate to combined multipurpose projects as discussed in the following sections. In many cases, solutions for future watersupply problems are in any case primarily associated with socioeconomic drivers (Reynard et al. 2014).

\subsection{Hydropower}

Larger new lakes constitute possible new reservoirs with high potential energy for hydropower production. Examples of detailed studies on the use of potential future lakes have been 
presented by Terrier et al. (2011, 2015) for the Swiss Alps (Figure 3). In intensely-exploited regions such as the European Alps, highly flexible energy storage in high-mountain water reservoirs with pump-storage capacity can play a key role in complex multi-component energy supply systems. Energy stored by pumping water to higher reservoirs in times of energy surplus (from other sources such as wind, solar or nuclear energy) can be accessed quasi immediately in case of a sudden peak demand. This possibility also constitutes a key safety
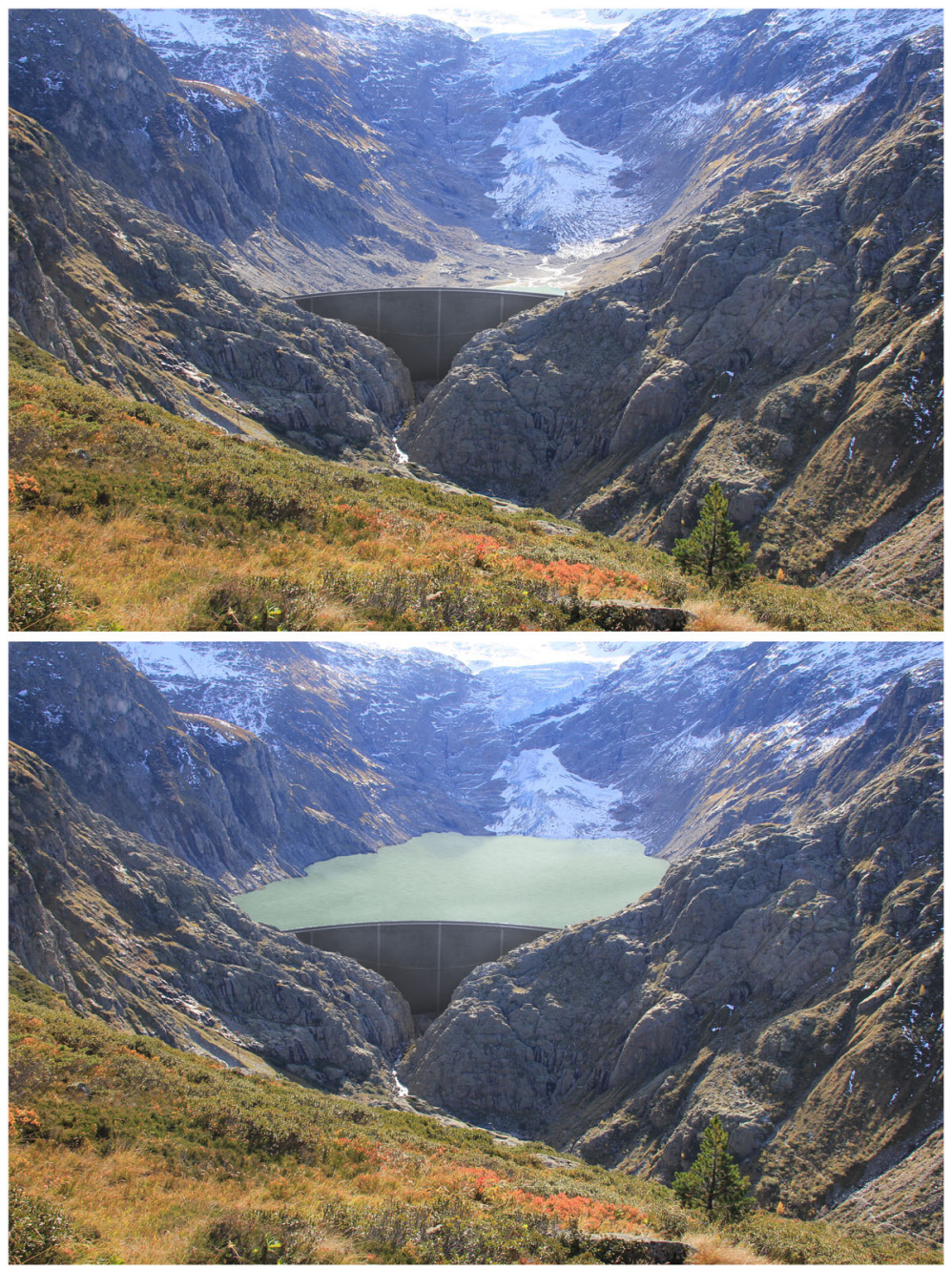

Fig. 3 Planned arch dam at Trift glacier, Swiss Alps, with lake existing today (top) and with full reservoir (bottom). Note that in comparison with the situation in 2007 (Figure 1), the connection between the steep glacier part and the flatter tongue disrupted in 2013. This has created a transitory increase in the hazard related to impact waves produced by ice avalanches into the lake. Further glacier shrinkage is likely to decrease this hazard soon, because of the disappearance of the steep upper glacier margin and of the detached glacier tongue; the latter currently provides a smooth ramp in a potential avalanche trajectory. Continued growth of the proglacial delta will further reduce potential impact waves. However, hazards from destabilizing lateral valley walls as a result of glacial de-buttressing will continue to exist for extended time periods into the future. The upper picture illustrates the flood retention capacity of the reservoir project. Photo composition by Kraftwerke Oberhasli (KWO) 
factor for avoiding the collapses of large energy networks. Fundamental problems in planning such options relate to the functioning of the energy market and the corresponding uncertainty about the energy price (Biot 2015). Nevertheless, under conditions of a free-electricity market, hydropower is the most competitive peak energy with high flexibility (Schleiss und Oberrauch 2014). Multipurpose projects offer promising perspectives; these include aspects of water supply and hazard protection, or efficient sediment traps protecting already existing downvalley reservoirs from rapid sediment infill. From the legal point of view, a string of acts and other legislation in the fields of spatial planning, water rights, landscape and water protection, nature conservation and preservation of cultural heritage must be taken into account with any construction project.

\subsection{Tourism}

Glaciers represent an important element of the tourism supply chain in cold mountains (Aall and Hoyer 2005; Espiner and Becken 2014; Scott and Jones 2005). Lakes can be important elements of landscape diversity, too. To some minor degree, the new lakes in de-glaciating areas may compensate for the loss of landscape diversity and attractiveness caused by vanishing glaciers in the sense of a "pulling power of the glacier experience" (Espiner and Becken 2014). Any expansion of the supply in the tourism system in a particular area necessitates protection against hazards in potentially unstable environments. This leads to cost/benefit-aspects that go beyond costs resulting from damage to infrastructure (Lehmann Friedli and Schaub 2013; Tzu-Ming 2014; Walters et al. 2015; cf. supplementary material S4). The new lakes in high-mountain regions are potentially dangerous beauties.

\subsection{Hazard prevention}

Floods and debris flows from lake outbursts can cause disastrous damage and high numbers of fatalities (Carey et al. 2012a; Clague and O'Connor 2014). With the formation of new lakes taking place closer and closer to high and steep icy peaks, the probability of impact waves from rock/ice avalanches into lakes is increasing (Haeberli et al. 2016). For the de-glaciated Alps, the area from which rock avalanches can detach and reach lakes is expected to increase by a factor around 3. The same is expected for the disposition intensity defined as a combination of factors favouring slope destabilization (Figure 4; Schaub 2015). This situation is likely to persist far into the future, because larger lakes will exist for extended time periods. In addition, changing surface/subsurface ice conditions (glacier de-buttressing, permafrost degradation) affect slope stability over centuries to millennia (Deline et al. 2014). Peak discharges from lake outbursts can far exceed values from precipitation-induced floods, causing rapid flows and devastation over distances of tens of kilometers (Cenderelli and Wohl 2001). Anticipating rapid and farreaching mass movements from destabilized slopes that interact with lakes, especially in relation to permafrost degradation and glacier retreat, requires both integrated assessment of the entire process chain (cf. Khanal et al. 2015) and anticipatory risk management (Frey et al. 2016). Considerable experience exists concerning measures for increasing lake safety; lakelevel lowering is a widely-used practice (Haeberli et al. 2001; Kääb et al. 2004; Portocarrero 2013), while flood retention in flat lower parts of potential trajectories or at lakes situated in lower parts of the involved catchments (cf. the case of Lake No 1 in Haeberli et al. 2001) can be an important option, especially in multipurpose projects. 


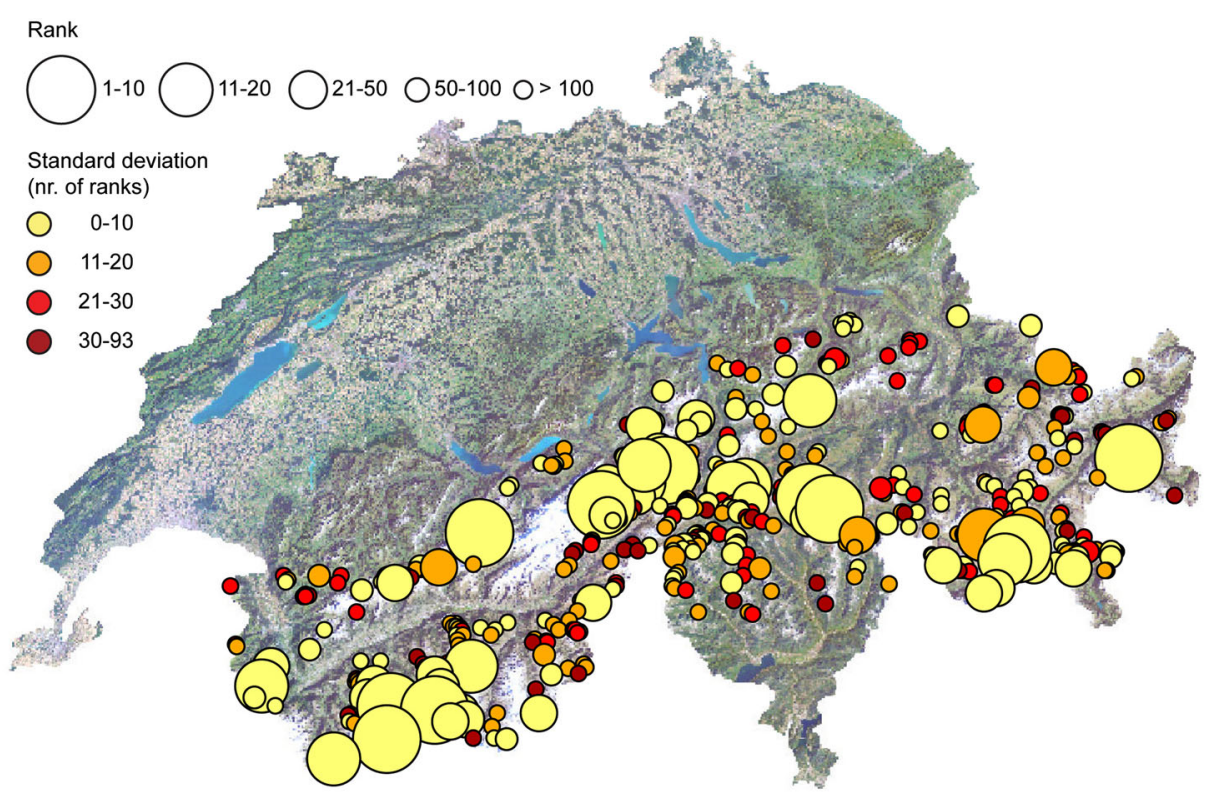

(a) Current rock-avalanche impact disposition

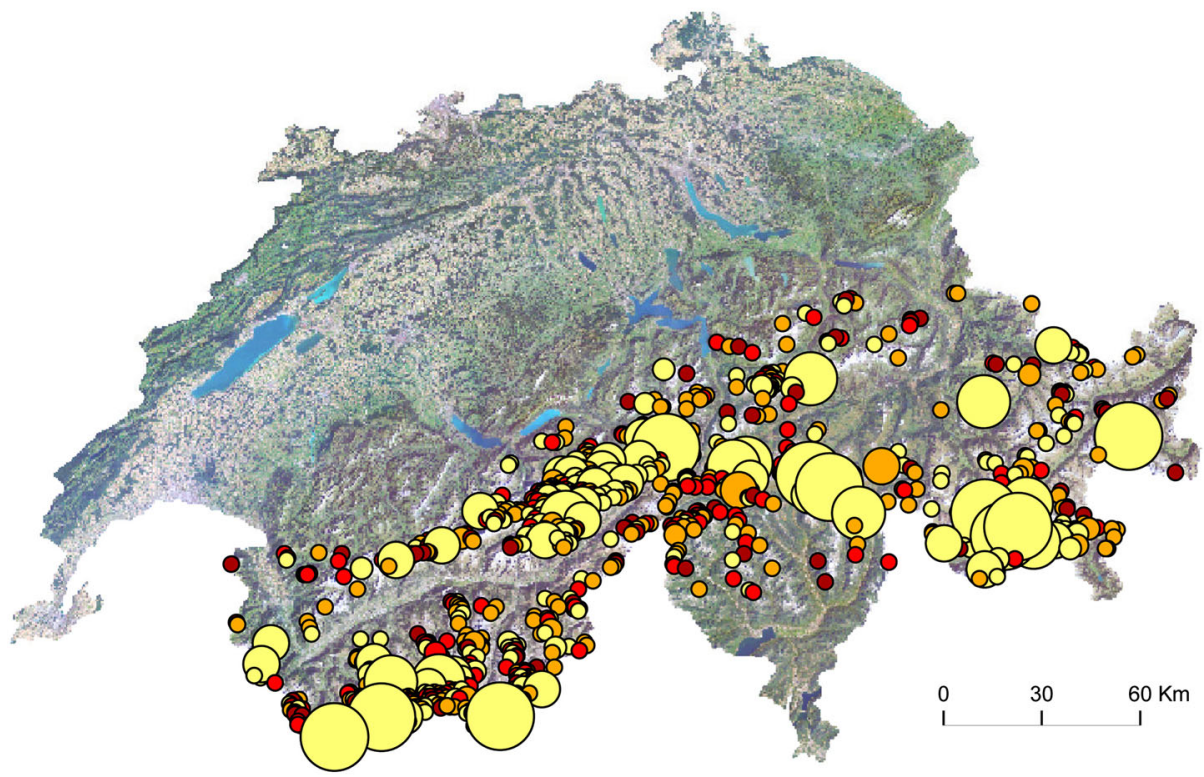

(b) Future rock-avalanche impact disposition

Fig. 4 Rock Avalanche Impact Disposition (RAID) index for all natural and artificial lakes in Switzerland above $1500 \mathrm{~m}$ a.s.l. existing in the $25 \mathrm{~m}$ DEM of swisstopo ("current condition", top) and, in addition, for all possible future lakes modelled by Linsbauer et al (2012) in still glacier-covered areas ("de-glaciated Swiss Alps", bottom). This impact index defines the possibility of a lake being reached by rock avalanches and the corresponding likelihood defined by the factors rock-wall slope, trajectory slope, lithology, degrading permafrost and deglaciation. The size of the circle indicates the rank of the lake according to its impact index, while the colour indicates the robustness of the rank. From Schaub (2015; cf. detailed discussion there) 


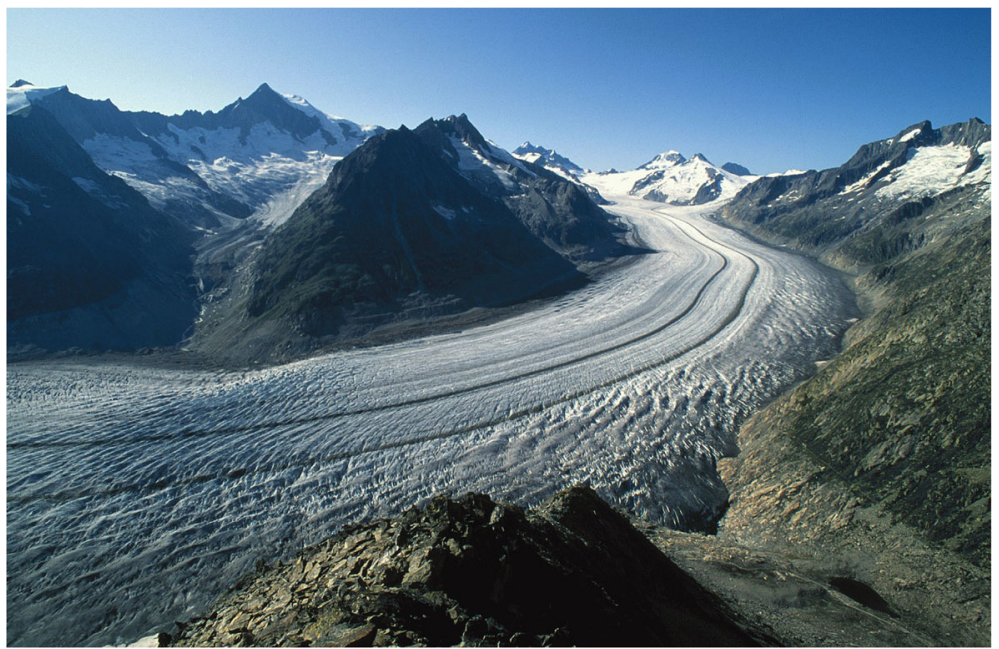

Fig. 5 The tongue of Aletsch glacier, the largest glacier in the European Alps and the key element of the UNESCO World Natural Heritage Swiss Alps Jungfrau-Aletsch, established in 2001. Even this large glacier is likely to disappear almost completely according to realistic warming scenarios. A sequence of medium to large lakes will probably form during the coming decades. Especially the lakes higher up in the catchment, probably forming in the second part of the century, will be surrounded by very high and steep slopes that tend to slowly destabilize as a consequence of glacial de-buttressing and permafrost degradation. Photograph F. Paul, August 1992

\subsection{Landscape protection}

Numerous regions with glaciers and ice-clad peaks are under special protection as national reserves, national parks, wilderness areas, biosphere reserves or special landmarks. Concerning glacier areas global warming overruns local to national protection goals; the landscapes cannot be kept in their current state but will be heavily impacted in their appearance and functioning. For example, the key feature of the UNESCO World Heritage Jungfrau-Aletsch in the Swiss Alps, is Aletsch glacier, also the largest glacier in the Alps (Figure 5). Within this century, this large ice body will most likely thin, retreat, disintegrate and give way to a landscape of bare rocks, debris, sparse vegetation, degrading permafrost and a series of new lakes (Haeberli et al. 2016). This strong and dramatic change means a new identity has to be developed for this region. The Huascarán National Park in the Cordillera Blanca contains numerous retreating glaciers and new lakes. What kind and extent of development for tourism, hazard prevention or hydropower production is appropriate here in accordance with spatial planning, transport laws and the protection goals? Any new exploitation generally tends to result in additional infrastructures, which in turn increase the pressure on landscape and biotopes even more.

\section{Potential synergies and conflicts}

All options concerning future developments with new lakes in de-glaciating high-mountain landscapes have their advantages and disadvantages. Synergies and/or conflicts are possible and to be expected. Decisions must be based on a careful evaluation of all aspects concerning complex geo-/ecosystems, human-environment relations, differing perceptions and diverse perspectives for the future. In such a context, even the polarity between synergy and conflict 
can become diffuse, if not ambivalent or even contradictory. The following brief and general example of a matrix analysis (Figure 6) provides a first impression. It is based on experience and a few case studies in Switzerland and Peru (Carey et al. 2012a, b; Lehmann Friedli and Schaub 2013; NELAK 2013), but may be taken as a starting point for more in-depth evaluations and integrative/participative planning at national to local levels elsewhere. The matrix enables an inter-comparison between the primary aspects for the management of future lakes with respect to potential synergies (upper part, green to white colours) and potential conflicts (lower part, red to yellow colours).

Interesting potential synergies (dark green in Figure 6) mainly exist in relation to multipurpose projects for flood retention, hydropower and water supply. Laguna Parón in the Cordillera Blanca - with a maximum volume of 79 million $\mathrm{m}^{3}$ the largest lake in the Rio Santa watershed - is not a "new" lake but was transformed in the 1970s and 1980s into such a multipurpose structure by regulating the lake level via an artificial tunnel through bedrock (Carey et al. 2012a; Portocarrero 2013). Already earlier (in 1951), it had withheld two outburst floods from Laguna Artesoncocha in the upper catchment. With an adequate freeboard, it can even absorb a large potential outburst flood from a new lake that now starts to form higher up in the catchment, at the tongue of Glaciar Artesonraju. A new lake is also expected to form towards the middle of the century at Glacier de Corbassière in the Swiss Alps (Terrier et al. 2011). Construction of a lake reservoir with regulation of the lake level would enable pumpstorage in combination with the already existing Lac de Mauvoisin. In addition, it could create an important retention capacity with respect to other lakes that will probably form further upvalley at the foot of the steep icy slopes of Grand Combin during the second half of the century. The fact that many such areas are situated in protected perimeters presents an additional aspect to be taken into consideration. Access infrastructure in connection with large projects can support economically-interesting but also ecologically-questionable touristic developments.

Construction for hydropower, flood retention, water supply, touristic infrastructure or corresponding multipurpose projects can be in strong conflict (intense red in Figure 6) with the applicable legal acts and codes, principles and goals of landscape protection, and nature conservation. This is especially the case for national reserves, national parks, biosphere

\begin{tabular}{|l|l|l|l|l|l|}
\hline \multicolumn{1}{|r|}{ Synergies } & Hydropower & Water supply & Hazard mitigation & Tourism & $\begin{array}{l}\text { Landscape / } \\
\text { Conservation }\end{array}$ \\
\hline Conflicts & & & & \\
\hline Wydropower & & & & & \\
\hline Hazard mitigation & & & & & \\
\hline Tourism & & & & & \\
\hline $\begin{array}{l}\text { Landscape/ } \\
\text { Conservation }\end{array}$ & & & & \\
$\square$ strong synergies \\
$\square$ weak synergies \\
$\square$ no synergies \\
\hline
\end{tabular}

Fig. 6 Matrix of potential synergies (upper part, green to white colours) and conflicts (lower part, red to yellow colours) concerning the management of new lakes in the Swiss Alps 
reserves, wilderness areas, etc., which are already under protection. Conflicts may also arise between hazard prevention and infrastructure for touristic development, because people should not be attracted to areas of increasing danger. An ambivalent relation exists for landscape protection/nature conservation and tourism. Touristic development necessitates new infrastructures, which in turn increase the pressure on landscape und biotopes. An artificial or artificially-enlarged lake can be a positive factor for landscape diversity in an otherwise monotonous de-glaciated rock/debris environment. However, this is only true as long as lake levels are kept high. Low water levels in managed lake reservoirs with exposed vegetation-free lakeshores look unnatural. Given the milky to brown colour of their water, caused by erosion of these vulnerable shores, they definitely deteriorate landscape appearance. Infrastructure enabling tourist access to new but remote high-altitude lakes can also add landscape disturbance. A similar ambivalence to conflict concerns hydropower, water supply and flood retention; low water levels are good for flood retention but not for hydropower production and freshwater supply. High water levels, on the other hand, reduce the protective function of a reservoir. It should be kept in mind that large technological investments can have unintended negative repercussions, and that any related political issues must be carefully incorporated into the analysis of social-ecological systems, hydro-social cycles and climate change adaptation (Carey et al. 2012b, 2014).

\section{Framework and options for planning and action}

Protection of human lives commonly and legally has a high priority; the protection of goods and assets is important but ranges on a lower level. In Switzerland, the territorially involved municipalities and cantons are responsible to a certain degree for protection from natural hazards, especially with respect to residential areas and traffic lines. Assessing and managing risks from potentially dangerous new lakes should therefore come first (cf. supplementary material S5).

Where large new lakes form or are likely to form in the foreseeable future, need for action exists. This need must be reflected and scrutinized in view of legal aspects, potential benefits and drawbacks, as well as possible synergies and conflicts. Legal aspects concern rights (e.g., ownership of the glacier areas or rights to use water concessions), responsibilities (especially protection of humans and infrastructure by political (e.g., administrative) authorities and by power-plant owners, and regulations. For the Swiss Alps and probably many other regions as well, the relevant fields in public law are spatial planning, transportation, natural hazard and environmental law (environmental, water, nature and homeland protection). Protected areas (biotopes, landscapes of national or international importance) are subject to stricter regulations than other areas; here the decisive factors are the actual circumstances of each site and project, together with the relevant national or international laws (Buetler 2006, 2007; NELAK 2013). Where new lakes develop or are artificially dammed in the catchment area of already existing hydropower schemes, rights and responsibilities may have to be redefined. Using hydropower reservoirs for flood protection or fresh-water supply may need regulations about financial compensation for losses in energy production. In protected areas, weighting of protection goals is necessary but can be delicate. The entire political framework with the involved stakeholders and decision paths comes into play. The framework for science essentially consists of (1) the framing and problem definition, (2) the scientific assessment of impacts, vulnerabilities 
and risks and (3) the evaluation of options and their possible implementation (Huggel et al. 2015). Since the drastic landscape changes in cold mountains have implications for communities and networks far beyond the limited icy areas alone, an open public discourse and participative planning can help to avoid unintended conflicts and adverse effects. An example of such conflicts recently occurred in the case of the regulated Laguna Parón in the Cordillera Blanca (Carey et al. 2012b), even though a combination of flood protection, hydropower production and water supply had already been pioneered at this site in the 1970s and 1980s (Portocarrero 2013). The relation between icy mountains and societies is marked by complex and often poorly understood processes of strong attribution, perception, and valuation by local and distant actors (Gagné et al. 2014; Orlove et al. 2008) and thereby constitutes a major challenge; this is especially the case when hazard and risk aspects change beyond the limits of historical-empirical knowledge (Huggel et al. 2008). Phenomena like subsurface permafrost degradation or locations of possible future lakes in still glacier-covered areas are not part of local experience from the past or direct visual observation. Communication and exchange of the scientific knowledge base therefore plays a key role.

\section{Conclusions and recommendations}

The formation of numerous new lakes in cold mountain ranges as a consequence of climateinduced ice vanishing necessitates consideration of increasing risks from natural hazards. At the same time, these lakes present new opportunities and challenges related to water management, hydropower production, touristic developments, landscape protection/nature conservation and corresponding legal questions. Studies and experiences in the Swiss Alps and the Peruvian Cordillera Blanca enable the following conclusions to be drawn and recommendations to be given:

- Realistic scenarios of climate-induced ice vanishing and resulting impacts on water resources, landscape evolution and natural hazards can be anticipated and described as a knowledge base for long-term planning.

- New lakes forming close to, or even directly at the foot of, destabilizing icy peaks function as hazard and risk amplifiers; floods and debris flows developing from impact waves triggered by rock/ice avalanches can affect down-valley areas over long distances and reach humans and their infrastructure in previously safe places.

- The new lakes also offer opportunities in connection with hydropower production, tourism and fresh water supply; multipurpose projects that combine flood retention, hydropower production and freshwater supply may be conducive to finding economic solutions.

- Legal aspects such as property and water rights, environmental laws and regulations on landscape protection/nature conservation must be carefully analysed and taken into consideration.

- The scientific basis for modelling future high-mountain landscapes without glaciers and corresponding process interactions needs further improvement; this should go hand-inhand with focused monitoring of changing landscapes and corresponding process dynamics in high-mountains to continuously assess changing hazard conditions.

- Integrative management of lakes appears to be the most appropriate and promising method in many cases; potential synergies and conflicts can be analysed in a comprehensive matrix-type approach involving all related stakeholders. 
- Constructive, future-oriented reflection should start soon; time for planning in view of the complex decision paths is short. Important first steps are the formation of an adequate knowledge base and awareness-building in terms of goals, technical tools, socio-economic aspects and judicial aspects are important first steps. Considerable uncertainties still remain, especially concerning future political and legal developments.

Acknowledgments The present contribution summarizes and reflects the main results of the project NELAK (new lakes as a consequence of melting glaciers: opportunities and risks) as part of the Swiss National Research Programme NRP 61 on Sustainable Water Management (http:/www.nfp61.ch/E/projects/clusterhydrology/lakes_melting_glaciers/Pages/default.aspx and http://www.vdf.ethz.ch/service/3533/3534_NeueSeen-als-Folge-des-Gletscherschwundes-im-Hochgebirge_OA.pdf); the project was funded by the Swiss National Science Foundation. We thank the Steering Committee of NRP 61 as well as all the colleagues and stakeholders from the scientific, administrative and economic sectors, who provided important input to our interand transdisciplinary project. This study has benefited from studies and experiences acquired in the Glaciares Project in Peru, funded by the Swiss Agency for Development and Cooperation (SDC) and in collaboration with CARE. We thank the editors and reviewers for their constructive feedback. Pamela Alean smoothed the English.

Author's contributions Wilfried Haeberli was the formal leader of the NELAK project, developed the structure of the present paper and drafted a first version based on the results and experiences gained in the NELAK project. All authors contributed to the project's results and participated equally in the elaboration of the final publication, with special emphasis on hazards and risks (Christian Huggel, Yvonne Schaub), on hydropower (Anton J. Schleiss), on tourism (Therese Lehmann Friedli) and on legal matters (Michael Buetler).

\section{References}

Aall C, Hoyer K (2005) Tourism and climate change adaptation: the Norwegian case. In: Hall M, Higham J (eds) Tourism, Recreation and Climate Change, Aspects of Tourism 22. Clevedon, pp 209-221

Allen SK, Linsbauer A, Randhawa SS, Huggel C, Rana P, Kumari A (2016) Glacial lake outburst flood risk in Himachal Pradesh, India: an integrative and anticipatory approach considering current and future threats. Nat Hazards. doi:10.1007/s11069-016-2511-x

Biot M (2015) Steigende Kosten, sinkende Preise - Wirtschaftlichkeit der bestehenden Kraftwerke. Bulletin VSE/AES 106(2):9-12

Buetler M (2006) Gletscher im Blickfeld des Rechts. Dissertation University of Zurich, Abhandlungen zum schweizerischen Recht 725, Bern

Buetler M (2007) Glaciers - objects of law and international treaties. In: Psenner R, Lackner R (eds) The Water Balance of the Alps - What do we need to protect the water resources of the Alps? Proceedings of the Conference held at Innsbruck University, 28-29 September 2006:19-31

Carey M, Huggel C, Bury J, Portocarrero C, Haeberli W (2012a) An integrated socio-environmental framework for glacier hazard management and climate change adaptation: lessons from Lake 513, Cordillera Blanca, Peru. Clim Chang 112(3):733-767

Carey M, French A, O’Brian E (2012b) Unintended effects of technology on climate change adaptation: an historical analysis of water conflicts below Andean Glaciers. J Hist Geogr 38:181-191. doi:10.1016/j. jhg.2011.12.002

Carey M, Baraer M, Mark BG, French A, Bury J, Young KR, McKenzie JM (2014) Toward hydro-social modeling: Merging human variables and the social sciences with climate-glacier runoff models (Santa River, Peru). J Hydrol 518(Part A):60-70. doi:10.1016/j.jhydrol.2013.11.006

Cenderelli DA, Wohl EE (2001) Peak discharge estimates of glacial-lake outburst floods and "normal" climatic floods in the Mount Everest region, Nepal. Geomorphology 40:57-90. doi:10.1016/S0169-555X(01)00037-X

Clague JJ, O’Connor JE (2014) Glacier-related outburst floods. In: Haeberli W, Whiteman C (eds) Snow and Icerelated Hazards, Risks and Disasters. Elsevier, p 487-519

Colonia D, Haeberli W, Torres J, Giraldez C, Schauwecker S, Santiago A, Cochachin A, Huggel C (2015) Possible future lakes in the Andes of Peru. Geophys Res Abstr 17:EGU2015-4500

Deline P, Gruber S, Delaloye R, Fischer L, Geertsema M, Giardino M, Hasler A, Kirkbride M, Krautblatter M, Magnin F, McColl S, Ravanel L, Schoeneich P (2014) Ice loss and slope stability in high-mountain regions. In: Haeberli W, Whiteman C (eds) Snow and Ice-related Hazards, Risks and Disasters. Elsevier, p 303-344 
Drenkhan F, Carey M, Huggel C, Seidel J, Oré MT (2015) The changing water cycle: Climatic and socioeconomic drivers of water-related changes in the Andes of Peru. WIREs Water (in press)

Espiner S, Becken S (2014) Tourists towns on the edge: conceptualising vulnerability and resilience in a protected area tourism system. J Sustain Tour 22(4):646-665

Farinotti D, Pistocci A, Huss M (2016) From dwindling ice to headwater lakes: could dams replace glaciers in the European Alps? Environ Res Lett II. 054022. doi:10.1088/1748-9326/11/5/054022

Faulkner B (2001) Towards a framework for tourism disaster management. J Tour Manag 22:135-147

French A, Barandiarán J, Rampini C (2015) Contextualizing conflict. Vital water and competing values in glaciated environments. In: Huggel C, Carey M, Clague JJ, Kääb A (eds) The High-Mountain Cryosphere. Cambridge University Press, Cambridge and New York, pp 315-336

Frey H, Huggel C, Bühler Y, Buis D, Dulce Burga M, Choquevilca W, Fernadez F, García Hernández J, Giráldez C, Loarte E, Masias P, Portocarrero C, Vicuña L, Walser M (2016) A robust debris-flow and GLOF risk management strategy for a data-scarce catchment in Santa Teresa, Peru. Landslides. doi:10.1007/s10346015-0669-z

Gagné K, Rasmussen MB, Orlove B (2014) Glaciers and society: attributions, perceptions, and valuations. WIREs Clim Chang. doi:10.1002/wcc.315

Haeberli W, Kääb A, Vonder Mühll D, Teysseire P (2001) Prevention of outburst floods from periglacial lakes at Grubengletscher, Valais, Swiss Alps. J Glaciol 47(156):111-122

Haeberli W, Schaub Y, Huggel C (2016) Increasing risks related to landslides from degrading permafrost into new lakes in de-glaciating mountain ranges. Geomorphology. doi:10.1016/j.geomorph.2016.02.009

Huggel C, Haeberli W, Kääb A (2008) Glacial hazards - perceiving and responding to threats in four world regions. In: Orlove B, Wiegandt E, Luckman BH (eds): Darkening Peaks - Glacial Retreat, Science and Society. University of California Press: $68-80$

Huggel C, Scheel M, Albrecht F, Andres N, Calanca P, Jurt C, Khabarov N, Mira-Salama D, Rohrer M, Salzmann N, Silva Y, Silvestre E, Vicuña L, Zappa M (2015) A framework for the science contribution in climate adaptation: Experiences from science-policy processes in the Andes. Environ Sci Pol 47:80-94. doi:10.1016/j.envsci.2014.11.007

Kääb A, Huggel C, Barbero S, Chiarle M, Cordola M, Epifani F, Haeberli W, Mortara G, Semino P, Tamburini A, Viazzo G (2004) Glacier hazards at Belvedere Glacier and the Monte Rosa east face, Italian Alps: processes and mitigation. Tenth Internationale Symposium Interpraevent 2004, 24-27 May 2004, Riva, Italy: 67-78

Khanal NR, Jin-Ming Hu J-M, Mool P (2015) Glacial lake outburst flood risk in the Poiqu/Bhote Koshi/Sun Koshi river basin in the Central Himalayas. Mt Res Dev 35(4):351-364. doi:10.1659/MRD-JOURNAL-D15-00009

Lehmann Friedli T, Schaub Y (2013) Neue Gletscherseen im Alpenraum - Schaden- und Nutzenpotenzial für den Schweizer Tourismus. Nachhaltigkeit im alpinen Tourismus, Schweizer Jahrbuch für Tourismus 2012: 111-126

Linsbauer A, Paul F, Haeberli W (2012) Modeling glacier thickness distribution and bed topography over entire mountain ranges with GlabTop: application of a fast and robust approach. J Geophys Res 117:F03007. doi:10.1029/2011JF002313

Linsbauer A, Frey H, Haeberli W, Machguth H, Azam MF, Allen S (2016) Modelling glacier-bed overdeepenings and possible future lakes for the glaciers in the Himalaya-Karakoram region. Ann Glaciol 567(71):119-130. doi:10.3189/2016AoG71A627

McEvoy D, Cavan G, Handley J, McMarrow J, Lindley S (2008) Changes to climate and visitor behaviour: Implications for vulnerable landscapes in the North West Region of England. J Sustain Tour 16(1):101-121

NELAK (2013) Neue Seen als Folge des Gletscherschwundes im Hochgebirge - Chancen und Risiken. Formation de nouveux lacs suite au recul des glaciers en haute montagne - chances et risques. Forschungsbericht NFP 61 (Haeberli W, Buetler M, Huggel C, Müller H, Schleiss A. (eds). Zürich, vdf Hochschulverlag AG an der ETH Zürich, 300p

Orlove B, Wiegandt E, Luckman BH (2008) Darkening peaks. Glacier retreat, science, and society. University of California Press, Berkeley CA

Portocarrero CA (2013) Reducing the risk of dangerous lakes in the Peruvian Andes: A handbook for glacial lake management. US Agency for International Development, Washington, DC

Reynard E, Bonriposi M, Graefe O, Homewood C, Huss M, Kauzlaric M, Liniger H, Rey E, Rist S, Schädler B, Schneider F, Weingartner R (2014) Interdisciplinary assessment of complex regional water systems and their future evolution: how socioeconomic drivers can matter more than climate. WIREs Water 2014(1):413-426. doi: $10.1002 /$ wat 2.1032

Ritchie B (2008) Tourism disaster planning and management: From response and recovery to reduction and readiness. Tour Disaster Plan Manag 11(4):315-348

Schaub Y (2015) Outburst floods from high-mountain lakes: Risk analysis of cascading processes under present and future conditions. PhD thesis, Geography Department, University of Zurich 
Schleiss A, Oberrauch F (2014) Flexibilisierung der Wasserkraft in der Schweiz für zukünftige Aufgaben im internationalen Strommarkt. Wasser Energie Luft 106(3):175-178

Scott D, Jones B (2005) Climate change and Banff National Park - implications for tourism and recreation. Faculty of Environmental Studies, Climate Change Action Fund, Ontario, Canada

Seibert J, Jenicek M, Huss M, Ewen T (2014) Snow and ice in the hydrosphere. In: Haeberli W, Whiteman C. (eds) Snow and Ice-related Hazards, Risks and Disasters, Elsevier:99-137

Terrier S, Jordan F, Schleiss AJ, Haeberli W, Huggel C, Künzler M (2011) Optimized and adapted hydropower management considering glacier shrinkage scenarios in the Swiss Alps. In: Schleiss A, Boes RM (eds) Proceedings of the International Symposium on Dams and Reservoirs under Changing Challenges - 79th Annual Meeting of ICOLD, Swiss Committee on Dams, Lucerne, Switzerland Taylor \& Francis Group, London: 497 - 508

Terrier S, Bieri M, Jordan F, Schleiss AJ (2015) Impact du retrait glaciaire et adaptation du potentiel hydroélectrique dans les Alpes Suisses. La Houille Blanche 70(1):93-101. doi:10.1051/lhb/2015012

Tzu-Ming L (2014) Analysis of the economic impact of meterological disasters on tourism: the case of typhoon Markot's impact on the Maolin National Scenic Area in Taiwan. Tour Econ 20(I):143-156

Walters G, Mair J, Ritchie B (2015) Understanding the tourist's response to natural disasters: the case of the 2011 Queensland floods. J Vacat Mark 21(I):101-113

Zemp M, Haeberli W, Hoelzle M, Paul F (2006) Alpine glaciers to disappear within decades? Geophys Res Lett 33:L13504. doi:10.1029/2006GL026319

Zemp M et al (2015) Historically unprecedented global glacier changes in the early 21 st century. J Glaciol 61(228):1-17. doi:10.3189/2015JoG15J017 